\title{
The History of Geosciences as the Resource for the Digital Space of Scientific Knowledge of the Russian Academy of Sciences
}

\author{
Irena Malakhova ${ }^{1[0000-0002-0478-7248]}$, Ivan Vtorov ${ }^{20000-0002-3345-3431], ~}$ \\ Sergey Kirillov ${ }^{3[0000-0001-7560-0041] ~}$ \\ 1, 2 Department for the History of Geology, Geological Institute of Russian Academy \\ of Sciences, Pyzhevsky lane 7, bld. 1, 119017, Moscow, Russia \\ ${ }^{3}$ Joint Supercomputer Center of Russian Academy of Sciences - Branch of Federal State \\ Institution "Scientific Research Institute for System Analysis" of Russian Academy \\ of Sciences, Leninskiy pr., 32a, 119334, Moscow, Russia \\ ${ }^{1}$ migeginras.ru, ${ }^{2}$ vip@ginras.ru, ${ }^{3}$ skirillov@jscc.ru
}

\begin{abstract}
The article describes the online Information System "History of Geology and Mining", its creation, use and development. Its Web content, structure and search capabilities provide direct access to information on contributions of numerous Russian and foreign geoscientist. The Information System contains personal bibliographies and lists of papers about geoscientists, as well as photos and documents about them. It provides easy search of scientific information, study of numerous original documents and meets all demands of users. The Information System is an important and useful tool for all professionals, historians of geosciences and students. The System may be considered as a working model of processing and digitising large collections of scientific information. The experience in the development and operation of the Information System can be scaled and integrated in other projects for the designed Common Digital Workplace of the Russian Academy of Sciences (RAS). Such integration should improve the quality of research works, increase citation, improve search and peer reviews of scientific works.
\end{abstract}

Keywords': Common Digital Space of Scientific Knowledge (CDSSK) of the Russian Academy of Sciences, Geological Institute, Department for the

\footnotetext{
${ }^{1}$ CDSSK-2020: International Conference “Common Digital Space of Scientific Knowledge”, November 10-12, 2020, Moscow, Russia

EMAIL:mig@ginras.ru (Irena Malakhova); vip@ginras.ru (Ivan Vtorov);

skirillov@jscc.ru (Sergey Kirillov);

ORCID: 0000-0002-0478-7248 (Irena Malakhova); 0000-0002-3345-3431 (Ivan Vtorov); 0000-0001-7560-0041 (Sergey Kirillov)

(c) (i) (c) 2021 Copyright for this paper by its authors. Use permitted under Creative Commons License Attribution 4.0 International (CC BY 4.0)

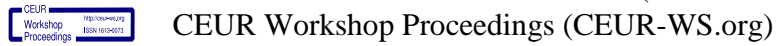


History of Geology, Information System, History of geology and mining, scientific database, history of science, history of geosciences.

\section{Introduction}

The creation of the Common Digital Space of Scientific Knowledge of the Russian Academy of Sciences is based on "existing information resources, both traditional and new, as they contain the experience of many generations of informational activity on the collection, processing and presentation of the knowledge" [1; quote translated from Russian, p. 20]. The initiators of this project propose to consider it as "a computer environment, by turning to which a user (from a scholar to a pupil) should be answered questions on any science" [2; quote translated from Russian, p. 729]. The Information System "History of Geology and Mining" (higeo.ginras.ru) is one of such resources.

The Information System was created by historians of geosciences and protected by a Russian patent for the database at the Geological Institute RAS [3]. This online resource meets such tasks of the Common Digital Space of Scientific Knowledge RAS as providing information for scientific research and study [4]. So the System preserves scientific knowledge and enhances understanding of the whole complex of geological and mining sciences. In this particular case, the history of geosciences could be taken as a unifying element for the Common Digital Space.

The history of science as a scientific field has emerged in Russia thanks to academician Vladimir I. Vernadsky (1863-1945). He was a mineralogist, a pioneer of geochemistry and an author of the Biosphere doctrine, a full member of the Imperial Academy of Sciences in Saint-Petersburg (1912). Vernadsky believed: "The study of a science in the past $<\ldots>$ always provides innovations into human consciousness" [5, quote translated from Russian, p. 17]. Vernadsky has defined the object for research, namely: the history of scientific thought. He combined a philosophical approach to the history of science with organisation of such activities. Vernadsky has initiated the foundation of the Commission on the History of Science of the RAS (founded in 1921) [6]. In 1930, he has proposed the research program on the history of science and technology, included collecting and processing information, publishing books, serial editions on the history of science with publishing scientific biographies [7]. In geology, this program started getting implemented by the famous scholar and traveler - an academician (1929) Vladimir A. Obruchev (1863-1956).

Obruchev had a great experience in geological researches and an amazing capacity for work. He single-handedly processed huge number of papers and reports and published a multivolume monograph "History of Geological Exploration of Siberia". It is the an annotated bibliography with scientific and biographical reviews about the explorers of Siberia [8]. The Obruchev's model of integrating and preserving of information on the history of geology was demanded by the "Commission on the Geological Study of the USSR" (1955-1991) which summarised the results of geological explorations by over 80 Soviet geological institutions, Academy of Sciences, Ministry of Geology, Ministry of Higher and Secondary Education [9]. The collective work resulted in the unique series "Geological Study of the USSR". It is divided into 50 regions of 
the USSR with several periods (1800-1980). Almost 1,050 books total published in 1962-1990 [10].

Since 1958 the Commission has been headed by Vladimir V. Tikhomirov (19151994) (Fig. 1). He was a man of unusual fate and remarkable abilities. He was a veteran of the Great Patriotic War, severely injured in 1944. The history of geological sciences in Russia is in debt to Tikhomirov for organising of such researches and involving of a wide range of geologists in this field of geosciences. Tikhomirov was elected as a corresponding member of the Academy of Sciences (1981) in recognition of his merits [10]. Tikhomirov is also credited with taking the lead of international cooperation in the history of geological sciences resulted with foundation of the International Commission on the History of Geological Sciences (INHIGEO) under the auspices of the International Union of History and Philosophy of Science (IUHPS) and the International Union of Geological Sciences (IUGS) in 1967. Tikhomirov was the first President of the Commission, and chaired for 9 years. His achievements were highly appreciated by the international geological community. The IUGS established a new medal - on the history of geosciences, for the first time since the $1^{\text {st }}$ Session of the International Geological Congress (Paris, 1878). Vladimir V. Tikhomirov Award in History of Geology was presented at the $23^{\text {rd }}$ Session of the Congress (Australia, 2012) [11].

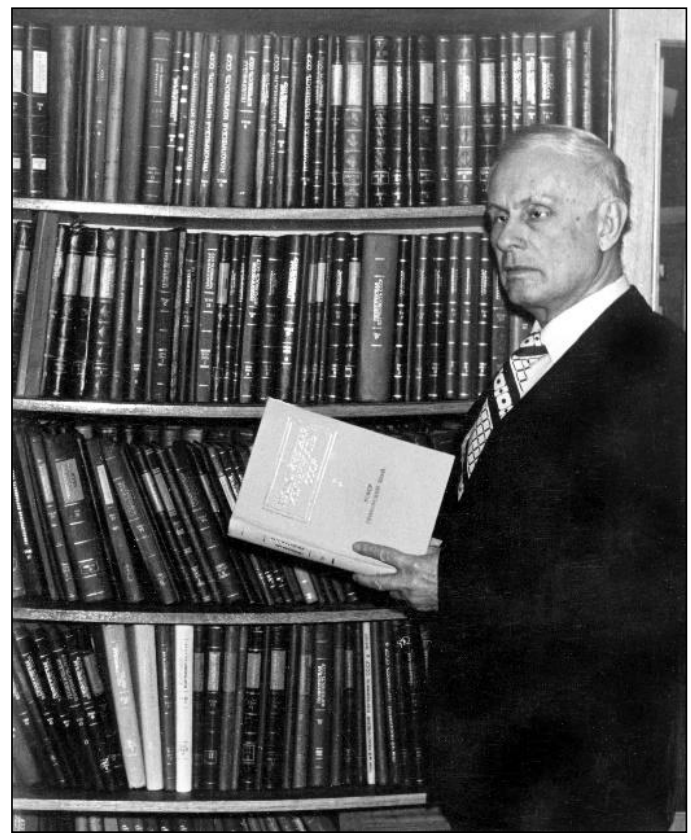

Fig. 1. Vladimir Tikhomirov with books "Geological Study of the USSR", Geological Institute AS USSR, Moscow, 1979 


\section{Data on the history of geology and mining}

Tikhomirov joined the Institute of Geological Sciences of the Academy of Sciences of the USSR in 1949. In 1951, with the support many geoscientists such as the first director of the Institute Obruchev and the head of the Department for Tectonics Nikolay S. Shatsky (1895-1960), he headed of the Department for the History of Geology and presided it over for four decades. The Institute itself, during its more than 90 years history changed its names: Geological Institute (1930-1937 and from 1956), Institute of Geological Sciences (1937-1956), nowadays it is called the Geological Institute RAS. Throughout the years, historians of geology have followed the Vernadsky's plan and the Obruchev's model. There was planned and systematic accumulation of data on the history of geology and mining by several generations of researchers.

Bibliographic information was collected and processed, resulting in a volume of over half a million units. Part of the material was published in 8 volumes of the Biographicalbibliographical Dictionary (1965-1978). The questionnaire method was actively used to collect biographical information. The obtained data was published in the volumes of the Great Soviet and Russian Encyclopedia and in many other reference works.

More than 6,000 personal folders of native and foreign geologists contain unique materials about scientists, gathered by the Department's staff as well as given by a large number of geologists and miners and received from numerous foreign colleagues. A separate collection contains folders on the history of scientific institutions. The Department is especially proud of a large stock of scientist's portraits. Over 20,000 photographs given by relatives and colleagues are still demand and used for scientific publications and events. The Department's library exceeds 5,000 volumes on geosciences and on the history of science.

The results of scientific work of the Department staff on the history of geosciences published in periodicals, collected articles in Russia and abroad. The series "Essays on the History of Geological Knowledge" initiated by Obruchev and continued by Tikhomirov has been ongoing since 1953. 32 issues have been published as collected articles and monographs, and most of them have been digitised and are accessible now on the website of the Geological Institute RAS (ginras.ru/library). The three-volume edition about members of the Academy of Sciences (academicians, corresponding members and foreign members) elected on science, geology and mining during the whole history of the Academy in Russia we consider as our recent achievements [1214].

The further activity of the Department of the History of Geology could not be limited only by the collection and use of geological data. We needed modern computer technologies for digital processing and presenting of our materials. The first attempts to transfer information into local catalogue files and databases could not help in solving the problem. The right way was found in cooperation with specialists in the field of information technologies of the Russian Academy of Sciences.

When the Department for the History of Geology was in the structure of the Vernadsky State Geological Museum RAS (1991-2015), it took part in the RAS Presidium Program - Digital Library "Scientific Heritage of Russia" (e-heritage.ru). This project combined information resources of scientific institutes, archives, libraries and 
museums of the RAS [15]. We have been testing approaches to the formation of digital resources reflecting texts and images with search capabilities on the Internet system during the work process on this Program. We entered this Project as the field "Geology" and were able to enrich the content with publications (monographs and articles) of geologists and mining engineers, scientific biographies, minerals named after geologists with portraits and other photos. We also took responsibility for the part "Museum Information", where the Museum mineral and paleontological collections were linked to persons and publications.

The work under the Program of the Presidium RAS and the study of experience of libraries and archives made it possible to find the right way to create our own information system. The experience of the staff of the Joint Supercomputer Centre RAS and the Library for Natural Sciences RAS enabled a group of historians of geology to develop the concept and determine the structure of the information system on geology and mining which has been opened in a test mode until 2015.

In 2015, the Department for History of Geology returned back to the Geological Institute RAS with its collections and the new information product. The Information System "History of Geology and Mining" is now fully operational. The resource is developing and may become a part of the future Common Digital Space of Scientific Knowledge of the RAS and could be taken as an acting model for systems on the history of sciences.

\section{Online Information System}

Information System "History of Geology and Mining" is the online database with information about scientists and institutions in such fields as geology and mining. It is the attempt to systematise and disclose data on the history of these sciences - the first of such kind in Russia and abroad.

We have defined the following tasks:

$\checkmark$ disclosure of scientific information based on primary sources;

$\checkmark$ processing, preserving and distribution of data;

$\checkmark$ providing multi-aspect search of information;

$\checkmark$ information support of scientific researches.

The Information System operates with the network configurable software package "SciRus" (Science of Russia) developed at the Library for Natural Sciences RAS [16, 17]. The System is directed toward both Russian speaking and foreign users. Names and surnames of persons are presented in Russian and in English. The website has a Russian and additional English interface. 


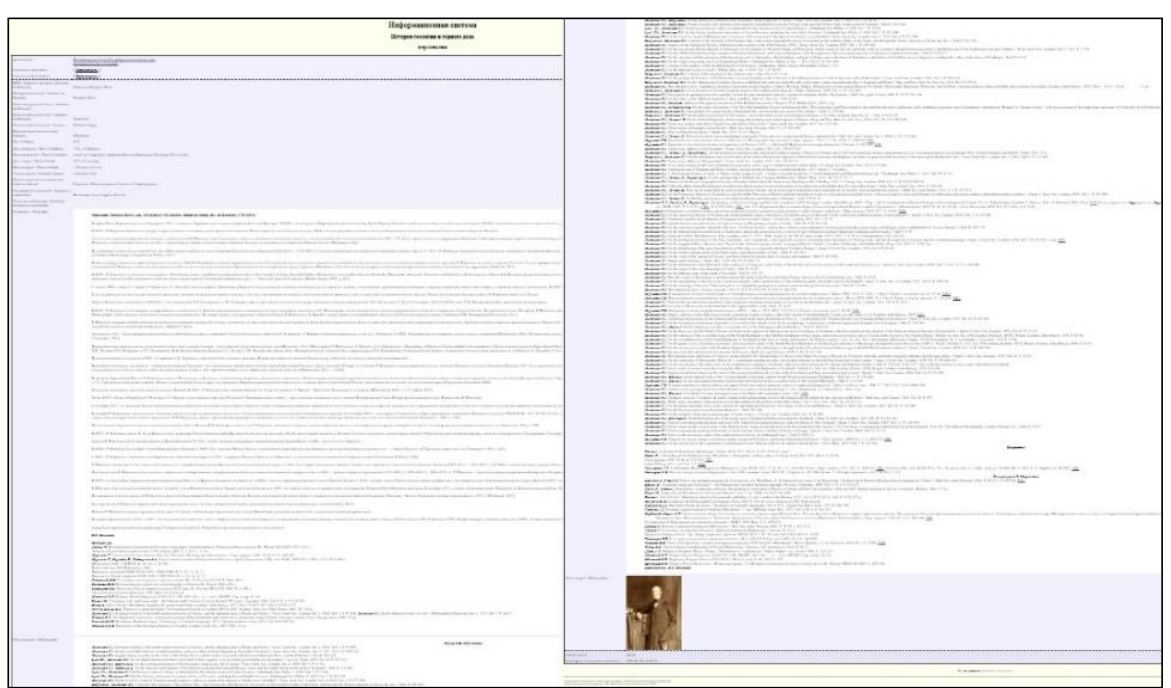

Fig. 2. Screenshots of the webpage about Roderick Murchison (1792-1871), Honorary member of the Imperial St. Petersburg Academy of Sciences, since 1845

The Information System is built and assembled according to the personal principle. The main objects are scientist personalities with other information connected: the places of work (institutions), bibliography, documents, photographs and other information with descriptions and sources. The personal information includes also main biographical data, fields of interest, geography of research works and full lists of publications and secondary literature (Fig. 2). Some bibliographical references are linked with available open Internet sources as full text publications.

The entity Institution is an important element of the Information System. Every person is linked with one or more institutions which contain exact titles. Types are defined (e.g. academy, research institute, university, society, etc.). Brief historical backgrounds are also provided. Additional information and lists of related persons are available through links and special search requests.

The Documents in the Information System are related to activities of scholars: autobiographies, memoirs, obituaries, correspondence, etc. The main attribute of a document is its facsimile and full text in PDF or HTML formats. A special attribute is an external Internet link to the URL (Uniform Resource Locator) or DOI (Digital Object Identifier) of an article, book or other publication of the document, stored on external websites [18].

Images (photos, mainly the portraits) as an important object associated with geoscientists have such attributes as "title" (with a year of photo) and "description" (some details and a source of an image). Some images may have direct HTML link with external sources.

The content of the Information System and its development is the responsibility of the Department for the History of Geology of the Geological Institute RAS. All staff members process available scientific data as planned and compile lists of publications 
and papers of new persons. The edited information in HTML puts in the Information System. All bibliographies and biographical articles are signed and may be cited and used for any direct scientific discussions.

All visitors have free access to the Information System content while only authorised editors of the Department for the History of Geology can add and edit information in HTML and add files. The Interface of the search options allows anyone to search for any objects by queries including any attributes. The result can be sorted by an attribute specified from a drop-down menu.

The System has started with the complete list (about 500 names) of full, corresponding and foreign members of the Russian Academy of Sciences elected for the whole its history (since 1724) in geology, mining, natural history and related geosciences. Looking for new names to add we are guided now by the next criteria:

$\checkmark \quad$ a role in the history of geosciences;

$\checkmark \quad$ the availability of data in our collection and in other sources;

$\checkmark$ members of main scientific societies and schools;

$\checkmark$ special requests (from scholars, institutions).

In November 2019, Information System "History of Geology and Mining" was registered as an electronic resource for collection, storage, presentation and analysis of information in the field of the Earth sciences [3]. By the July, 2021 the list of represented persons exceeded 1,230 names of Russian and foreign geologists and mining engineers. The number is increasing annually by more than 100 scientists. The current content of the Information System also includes over 700 institutions, 770 document files, and 1,530 images.

The key functionality is the internal integrated search by many user-selectable parameters that make up the structure of the Information System. The array of requested data is concentrated around each person and includes:

$\checkmark$ biographical data (questionnaires, references, scientific biographies);

$\checkmark$ affiliated institutions (with lists of scientists linked);

$\checkmark \quad$ fields of interest (under the Code of Russian State Categories Scientific and Technical Information);

$\checkmark$ geography of explorations (study areas described in papers);

$\checkmark \quad$ lists of publications, obituaries papers about person and other secondary literature (bibliographies with URL and DOI, if available);

$\checkmark$ documents: autobiographies, programs of commemoration events, correspondence, papers (mostly in PDF format);

$\checkmark$ photographic portraits of scientists and other images (in JPG format).

All these parameters are easy to select in a drop-down search menu (Fig. 3). Navigation and data aggregation is done via corresponding links. 


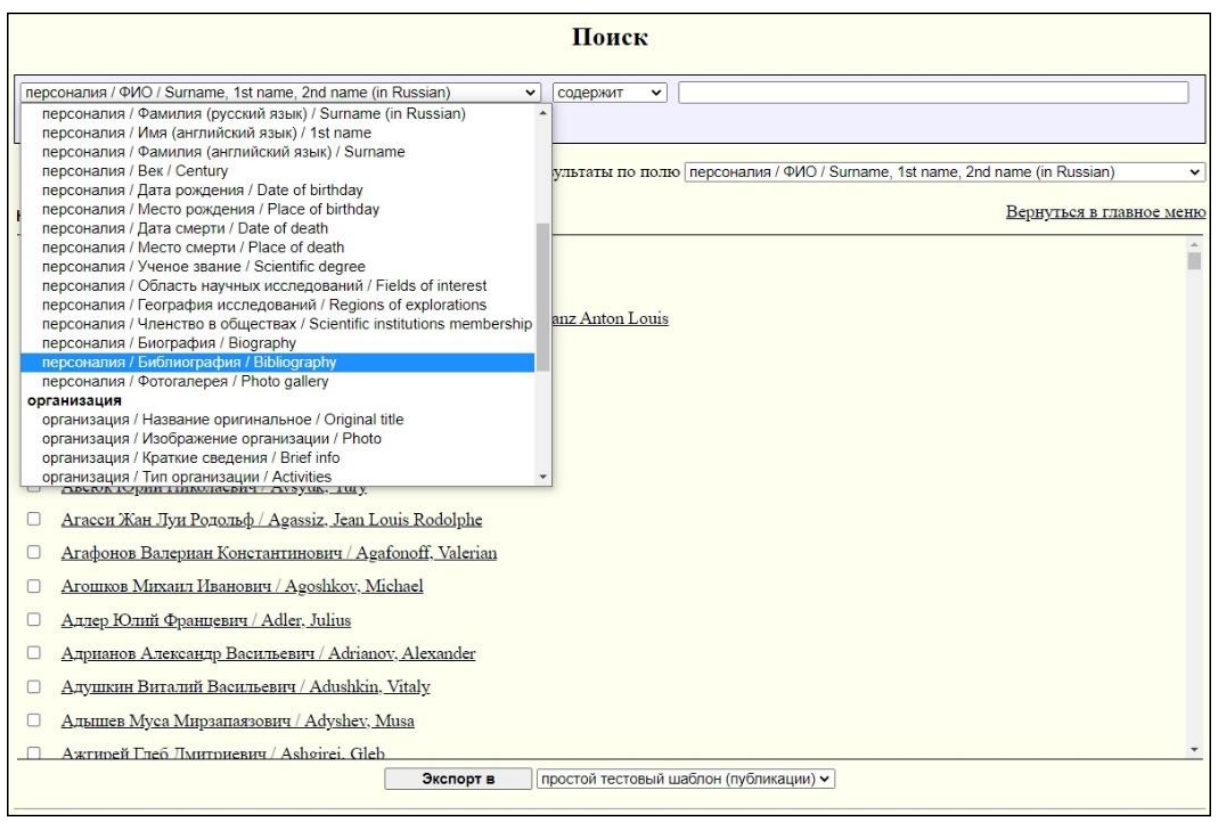

Fig. 3. Screenshot of scientists names and the drop-down menu with search options

\section{The experience and development of the Information System}

The Information System provides access to structured and edited information on the history of geology and mining. Main international Internet search engines index the System content. It expands the audience of its users and makes it more accessible and recognisable.

The Information System continues to evolve by expanding the list of personalities, bibliographies of their works and documents. The Geological Institute exchanges data with historians of science and collaborates with other institutions. It helps to obtain upto-date information from them to add to the System. The extensive and diverse content has already made it a notable information resource and a tool for work of geoscientists and historians of science [19].

Since 2017, the System's content has been used in the course "History of Geology" by magistrates of the Geological Faculty of the Lomonosov Moscow State University. Wikipedia considers the Information System as an authoritative scientific source of information, so its pages have over 600 direct links from various articles in Russian-language Wikipedia and templates have been created to integrate them automatically. In December 2019, a meeting with Wikipedia editors was held at the Department for the History of Geology of the Geological Institute RAS to demonstrate its capabilities and received feedback.

Web statistics shows an increasing interest to the Information System. For example, during last three years $70 \%$ of the traffic came from external search engines and $23 \%$ 
from links on various websites. In total there were 143,683 page views from 26,477 unique visitors. The main users were Russian-speaking: from Russia (92\%) and other $4 \%$ comes from other former USSR countries (Tab. 1). Thus, the main users were residents of the Russian capital region, while residents of Africa hardly use the System. However, we can see from the available statistics that men and women were equally distributed ( $51 \%$ and $49 \%$ ); $67 \%$ of users were over 45 , and only $12 \%$ were students (18-24 age).

Table 1. Information System views distribution, in thousands for last 3 years (Yandex Metrika web data, by July 31, 2021)

\begin{tabular}{|c|c|c|c|}
\hline \multicolumn{2}{|c|}{ Top 10 countries } & \multicolumn{2}{|c|}{$\begin{array}{l}\text { Top } 10 \text { Russian regions } \\
\text { (city with its region) }\end{array}$} \\
\hline Russia & 131.5 & Moscow & 96.8 \\
\hline Ukraine & 1.4 & Saint Petersburg & 7.6 \\
\hline Kazakhstan & 1.2 & Ekaterinburg & 2.0 \\
\hline Germany & 1.0 & Novosibirsk & 1.8 \\
\hline USA & 0.9 & Syktyvkar & 1.3 \\
\hline Belarus & 0.9 & Irkutsk & 1.0 \\
\hline Lithuania & 0.8 & Perm & 0.8 \\
\hline Uzbekistan & 0.4 & Vladivostok & 0.8 \\
\hline Armenia & 0.4 & Ufa & 0.8 \\
\hline Great Britain & 0.3 & Krasnodar & 0.7 \\
\hline
\end{tabular}

The content of the Information System is cited in books, articles and reports on the history of science. Members of the Department for the History of Geology have demonstrated and discussed the capabilities of the Information System at several scientific conferences in Russia, among them:

$\checkmark$ Information Support for Science: New Technologies (2011, 2017, 2020);

$\checkmark \quad 15^{\text {th }}$ Annual International Conference "EVA-2013": Information Society, Culture, Education: Libraries and Museums in Digital Environment: Dialogue and Cooperation (2013);

$\checkmark 16^{\text {th }}$ Geological Congress of the Komi Republic in Russia (2014);

$\checkmark$ Information Resources Collective Use Centres and Unique Scientific Facilities in organisations subordinate to the Federal Agency of Scientific Institutions RAS (2015);

$\checkmark \quad 8^{\text {th }}$ All-Russian Geological Congress: Round Table (2016);

$\checkmark \quad$ Annual Scientific Conference of the Sergey Vavilov Institute for the History of Science and Technology RAS (2019).

In addition, the Information System was demonstrated (in English) at international scientific meetings of historians of geology and mining, among them:

$\checkmark \quad 12,13$ and $15^{\text {th }}$ Erbe-Symposium: Cultural Heritage in Geosciences, Mining and Metallurgy: Libraries - Archives - Collections (2013, 2015, 2021); 
$\checkmark \quad 42^{\text {nd }}$ Symposium International Commission on the History of Geological Science (INHIGEO) (2017).

Discussing the work with the Information System some tasks for its improvement became clear, among them:

$\checkmark \quad$ Small text of the first bibliographies (font size 8 points), which is gradually corrected with general HTML Style (12 points) when updating data;

$\checkmark$ Some textual abbreviations in bibliographic descriptions spoil search accuracy and use in references; it's clear for short paper publications and not necessary for digital ones; a list of abbreviations would help to solve the problem;

$\checkmark \quad$ Direct links with full-text publications (external HTML links to URL and DOI) in some bibliographies done few years ago may be failed as their address sometimes change, or the site becomes closed over time; the only way to recover such a link is to use new archive links (web.achive.org);

$\checkmark$ Some restrictions on publications of living scientists' personal data in Russia limits us to operate with only published information about them.

An undoubted advantage of the online Information System in comparison with printed publications of reference information on the history of geology, is:

$\checkmark$ Quick and easy posting and spreading of scientific information;

$\checkmark$ Maintenance of up-to-date information and the possibility of its edition;

$\checkmark \quad$ Internal and external search options and availability of information.

The System provides interaction with a large volume of data and a new style of scientific work on the history of geosciences. So, it becomes more and more trustworthy, verifiable and authoritative as it is getting more content.

\section{Conclusion}

The Information System "History of Geology and Mining" is the result of the collective work of the small team of historians of science in the field of geological knowledge.

Large volume of information resources required modern online IT technology as the most effective way of data accumulation, its synthesis and disclosure.

The project has been realised through collaboration with specialists of the Russian Academy of Sciences.

The experience of the Information System "History of Geology and Mining" can be used as a working model in this emerging the data about history of other sciences in a new scientific environment to be managed by the Russian Academy of Sciences. It may be the right way to process and digitise large collections of scientific information.

The experience of development and operation of the Information System can be scaled and integrated into other Web projects. Digital online integration should improve 
the quality of research works, increase citation, improve search and peer reviews of scientific works

We look forward to any discussions and cooperation in working out of regulations and standards for developing and editing of scientific content and modern functionality for compatibility, scalability of information systems and unification of publications in the new Common Digital Space of Scientific Knowledge of the Russian Academy of Sciences.

\section{References}

1. Antopol'skij, A.B.: O razrabotke edinogo cifrovogo prostranstva. Nauchnoe izdanie mezhdunarodnoro urovnya - 2019: stragegia taktika upravlenia I razvitiya: materialy 8 Mezdunarodnoi nauchno-prakycheskoj konferenzii. Ekaterinburg: Izdatel'stbo Ural'skogo federal'nogo universiteta. S. 17-29 (2019), https://doi.org/10.24069/konf-23-26-042019.02

2. Antopol'skij, A.B., Kalenov, N.E., Serebryakov, V A., Sotnikov, A.N.: O edinom cifrovom prostranstve nauchnykh znanij. Vestnik Rossijskoj akademii nauk 7. S. 728-735 (2019).

3. Informacionnaya sistema "Istoriya geologii i gornogo dela". State registration of the database protected by copyright \# 2019622087, Russian Federal Service for Intellectual Property, Moscow (15.11.2019).

4. Kalenov, N.E., Savin, G.I., Sotnikov, A.N.: Arkhitektura edinogo cifrovogo prostranstva nauchnykh znanij. Edinoe cifrovoe prostranstvo nauchnykh znanij: problem I reshenija. Moskva; Berlin: Direktmedia Publishing. S. 7-16 (2021), https://doi.org/10.23681/610687

5. Vernadskij, V.I.: Mysli o sovremennov znachenii istorii znannij: Doklad proxbnfnnyj na 1 zasedanii Komissii po istorii znanij. 14.10.1926. Leningrad: Izdatel'stvo Akademii Nauk SSSR. 17 s. (1927).

6. Vernadskij, V.I.: Zapiska o neobkhodimosti sozdanija Komissii po izucheniyu istorii nauki, filosofii b tekhniki. Izvestia Rossijskoj Akademii nauk. Seriya 6. Protokoly. 1-18 (15). S. 1012 (1921). URL: http://mi.mathnet.ru/rus/izv/v15/p1

7. Vernadskij, V.I.: Zapiska o zadachakh Komissii po istorii znanij (KIZ). Arkhiv Rossiyskoj Akademii nauk. Fond 518. Opis' 4. Delo 48. List 42 (1930).

8. Obruchev, V.A.: Istorija geologicheskogo issledovaniya Sibiri: V 5 tomakh; 9 vypuskov. Moskva; Leningrad: Izdatel'stvo Akademii nauk SSSR (1931-1949, 1959).

9. O deyatel'nostu Komissii po geologicheskoj izuchennosti SSSR. Vestnik Akademii nauk SSSR11. S. 13-15 (1983).

URL: http://www.ras.ru/publishing/rasherald/rasherald_articleinfo.aspx?articleid=364ecb2 4-3fe6-4cd0-a6d8-f455578aaa52

10. Laverov, N.P., Malakhova, I.G.: Viennoe muzhestvo i grazhdanskij podvig: K 100-letiyu so dnya rozhdeniya chlena-korrespondenta RAN V.V. Tikhomirova. Vestnik Rossijskoj Akademii Nauk 10. S. 937-939 (2015).

11. Malakhova, I.: The founding of INHIGEO: documents and letters, with comments // Celebrating 50 Years of INHIGEO / Eds. W. Mayer, R.M. Clary, L.F. Azuela, N.S. Mots \& S. Wolkowicz. London: GSL, 2017. P. 9-19 (GSL Special Publication; 442). http://dx.doi.org/10.1144/SP442.38

12. Solovjev, Yu.Ya., Bessudnova, Z.A., Przhdetskaya, L.T.: Otechestvennye dejstvitel'nye I pochentye chleny Rossijskoj akademii nauk. XVIII-XX vv. / Otv. red. Yu.Ya. Solovjev. Moskva: Nauchnij mir. 548 p. (2000). 
13. Solovjev, Yu.Ya., Khomizuri, G.P., Bessudnova, Z.A.: Otechestvennye chleny-korrespondenty Rossijskoj akademii nauk. XVIII-nachalo XX veka: geologiya i gornye nauki / Otv. red. Yu.Ya. Solovjev. Moskva: Nauka. 607 s. (2007).

14. Malakhova, I.G., Bessudnova, Z.A., Khomizuri, G.P., Minina, E.L.: Inostrannye chleny Rossijskoj akademii nauk. XVIII-XXI vv.: geologiya i gornye nauki / Otv. red. I.G. Malakhova. Moskva: Nauka, Geofizicheskij centr RAN. 504 s. (2012). URL: http://elpub.wdcb.ru/ebooks/formemb.pdf

15. Kalenov, N.E., Savin, G.I., Serebryakov, V.A., Sotnikov, A.N.: Printsipy postroenija I formirobanija electronnoy biblioteki "Nauchnoye nasledie Rossii". Programmnye Produkty i Sistemy 4 (100). S. 30-40 (2012).

16. Sen'ko, A.M.: Informatzionnaya sistema SciRus: printsipy postroenija i perspektivy razvitija. Nauchnyj servis $\mathrm{v}$ seti Internet: tekhnologii parallel'nogo programmrovaniya. Moskva. S. 58-59 (2006).

17. Yakshin, M.M.: Razvitie platform SciRus. Informatsionnoye obespechenie nauki: novye tekhnologii. Moskva: BEN RAN. S. 203-207 (2015).

18. Kalenov, N.E., Malakhova, I.G.: Integrirovanny'j obshhedostupny'j informacionny'j resurs "Istoriya geologii i gornogo dela". Informacionny'e Resursy Rossii 1. S. 19-23 (2017).

19. Vtorov, I.P.: The Information System "History of Geology and Mining" as a scientific tool for historians of Earth sciences. IOP Conference Series: Earth and Environmental Science 350. pp. 012020 (2019). https://doi.org/10.1088/1755-1315/350/1/012020 